\title{
POSOUZENÍ EKONOMICKÉ VÝHODNOSTI NÁVRHU OBNOVITELNÉHO ZDROJE ENERGIE VE FORMĚ FTV PANELŮ: PŘíPADOVÁ STUDIE PRO BYTOVÝ DŮM
}

\author{
ASSESSING THE ECONOMIC BENEFITS OF A RENEWABLE ENERGY DESIGN \\ IN THE FORM OF FTV PANELS: A CASE STUDY FOR A RESIDENTIAL BUILDING
}

\author{
Bc. Václav Sotoláŕr ${ }^{*}$; Ing. Michal Brandtner ${ }^{1}$; Ing. Adam Boháček \\ ${ }^{1}$ Brno University of Technology, Faculty of Civil Engineering, Veveři 331/95, 60200 Brno, Czech Republic \\ * corresponding author: 176490@vutbr.cz
}

\begin{abstract}
ABSTRAKT CZ
Článek se zabývá problematikou využití slunečního záření jako obnovitelného zdroje energie v rámci budovy bytového domu. V současné době je aktuálním trendem využívat jakékoliv ekologické obnovitelné zdroje energie. Podstatnou část těchto zdrojů energie tvoří sluneční záření. Sluneční záření je možné při návrhu budovy využít dvěma hlavními způsoby, a to bud' k výrobě elektřiny pomocí fotovoltaických (FTV) panelů nebo k získávání tepla k ohřevu teplé vody pomocí solárních termických kolektorů. Fotovoltaické panely se používají pro výrobu elektrické energie díky světelnému záření. Článek se dále rovněž věnuje energetickému využití a finančnímu posouzení FTV panelů instalovaných na větrané fasádě konkrétního objektu. Benefity jsou prezentovány na konkrétní prrípadové studii reálné stavby bytového domu.
\end{abstract}

Klíčová slova: Fotovoltaické panely, FTV, větraná fasáda, obnovitelné zdroje energie, životní prostředí, náklady, bytový dùm.

\section{ABSTRACT}

The article deals with the use of solar radiation as a renewable energy source for apartment building. Today, it is actual trend to use any ecological renewable energy sources. A substantial part of these energy sources is solar radiation. Solar radiation can be used in the design of a building in two main ways, either to generate electricity using photovoltaic (PV) panels or to generate heat hot water using solar thermal collectors. Photovoltaic panels are used to generate electricity due to light radiation. The article also deals with the energy use and financial assessment of PV panels installed on the ventilated facade of a particular building. The benefits are presented on a specific case study of a real apartment building.

Key words: Photovoltaic panels, PV, ventilated facade, renewable energy sources, environment, costs, apartment building.

\section{1 ÚVOD}

V současné době je moderní využívat jakékoliv ekologické a obnovitelné zdroje energie. $O$ to více se rozmáhá fotovoltaika, kterou lze využít několika způsoby a je tzv. „multifunkční“. Největším zdrojem energie je sluneční záření. Sluneční záření je možné využít dvěma způsoby, a to bud' k výrobě elektřiny pomocí fotovoltaických (FTV) panelů nebo k získávání tepla k doi.org/10.51704/cice.2020.vol6.iss2.pp59-70 
ohřevu teplé vody pomocí solárních termických kolektorů. Sluneční energie poskytuje ideální kombinaci ekologie a hospodárného vytápění. FLV panely se používají pro výrobu elektrické energie, která se vyrobí díky světelnému záření, nikoliv však tepelnému. FTV článek je zařízení, které přeměňuje sluneční energii přímo na energii elektrickou.

\subsection{Legislativa a obecně závazné předpisy}

Návrh, realizace a provozování systémů na výrobu energie z obnovitelných zdrojů podléhají především následujícím právním předpisům a normám:

- zákon č. 22/1997 Sb., v aktuálním znění zákon č. 265/2017 Sb., o technických požadavcích na výrobky a o změně a doplnění některých zákonů

- zákon č. 165/2012 Sb., v aktuálním znění zákon č. 131/2015 Sb., o podporovaných zdrojích energie a o změně některých zákonů

- vyhláška č. 194/2015 Sb., o způsobu regulace cen a postupech pro regulaci cen v elektroenergetice a teplárenství

- vyhláška č. 296/2015 Sb., v aktuálním znění vyhláška č. 266/2016, o technickoekonomických parametrech pro stanovení výkupních cen pro výrobu elektřiny a zelených bonusů na teplo a o stanovení doby životnosti výroben elektřiny a výroben tepla z obnovitelných zdrojů energie (vyhláška o technickoekonomických parametrech)

- vyhláška č. 477/2012 Sb., o stanovení druhů a parametrů podporovaných obnovitelných zdrojů pro výrobu elektrriny, tepla nebo biometanu a o stanovení a uchovávání dokumentů

- nařízení vlády č. 118/2016 Sb., o posuzování shody elektrických zařízení určených pro používání v určitých mezích napětí při jejich dodávání na trh

- C ČSN 330360 ed. 2 Místa připojení ochranných vodičů na elektrických předmětech

- ČSN 33 2000-4-41 ed. 2 Elektrické instalace nízkého napětí - Část 4-41: Ochranná opatření pro zajištění bezpečnosti Ochrana před úrazem elektrickým proudem

- C ČSN 33 2000-5-51 ed. 3 Elektrické instalace nízkého napětí - Č́st 5-51: Výběr a stavba elektrických zařízení - Všeobecné předpisy

- ČSN 33 2000-7-712 ed. 2 Elektrické instalace nízkého napětí - Č́at 7-712: Zařízení jednoúčelová a ve zvláštních objektech - Fotovoltaické (PV) systémy, a další

\section{TEORETICKÁ VÝCHODISKA}

\subsection{Fotovoltaické panely}

\subsubsection{Technologie FTV panelů}

Fotovoltaické panely se používají pro výrobu elektrické energie, která se vyrobí díky světelnému záření, nikoliv však tepelnému. Nejznámější fotovoltaické panely jsou z křemíkových článků (krystalických článků), ve kterých vzniká stejnosměrný proud. Vyrobený proud je sveden speciální kabeláží do stř́ídače napětí. Stejnosměrný elektrický proud se přemění na střídavý elektrický proud. Odtud je elektrický proud rozveden do akumulátorového uložiště elektrické energie, nebo do domácí elektrické sítě. V případě přebytku elektrické energie lze zásobovat energií distribuční elektrickou sít'. [1] 
Výroba fotovoltaické energie je jedním z nejrychleji rostoucích zdrojů energie, který je ovlivňován množstvím slunečního záření a teplotou fotovoltaického panelu. Účinnost fotovoltaických panelů klesá s rostoucí teplotou. Článek [2] se zabývá experimentálním zkoumáním výkonu fotovoltaického panelu s využitím materiálů pro fázovou změnu (PCM). Tyto materiály mohou při použití na zadní straně panelu absorbovat značné množství tepla a tím zvýšit jejich výstupní výkon.

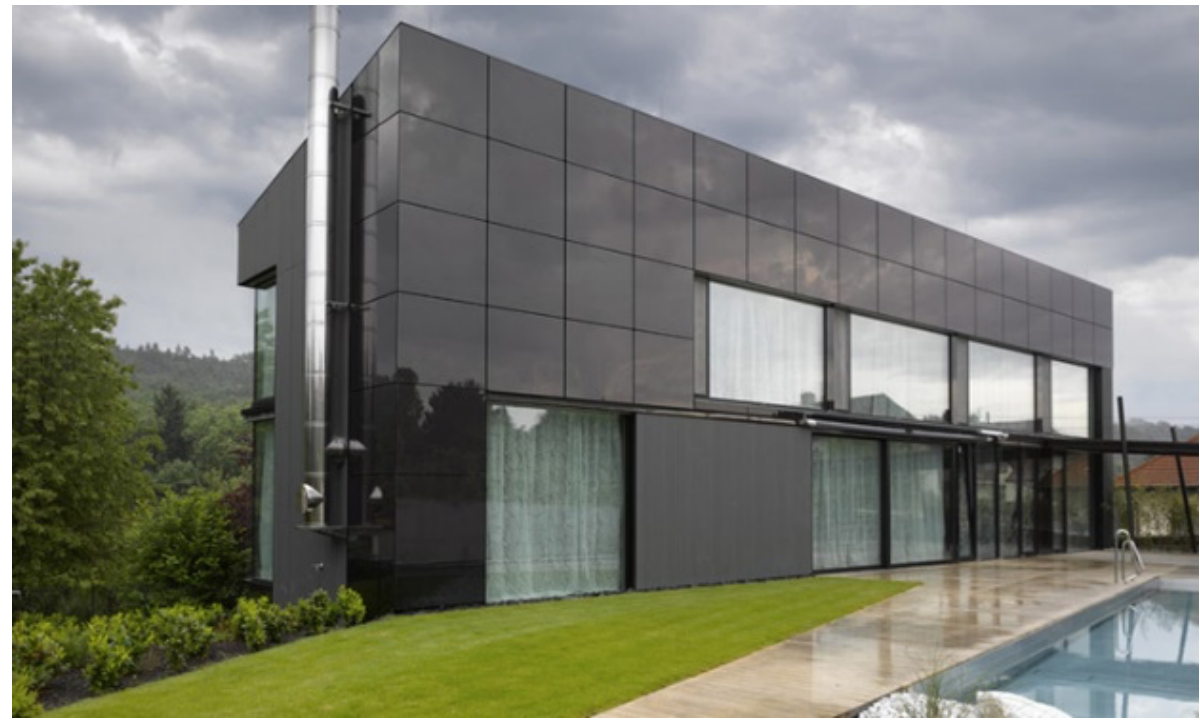

Obr. 1 Fotovoltaická fasáda na rodinném domě [3]

\subsubsection{Fyzikální podstata FLV přeměny energie}

FTV článek je zařízení, které přeměňuje sluneční energii přímo na energii elektrickou. FTV články se vyrábějí z materiálů, které nazýváme polovodiče. Základním materiálem polovodiče je křemík. Ten má však tu nevýhodu, že v surovém stavu je velmi špatný vodič elektrického proudu. Z tohoto důvodu se kombinuje křemík s dalšími prvky, jako je fosfor a bor. Polovodiče, které vzniknou smícháním křemíku a fosforu, mají nadbytek elektronů. Tyto polovodiče se označují jako polovodiče typu N. Polovodiče, které vzniknou smícháním křemíku a boru, mají naopak nedostatek elektronů. Místa, kde elektrony chybí, se nazývají díry. Tyto díry mají kladný elektrický náboj, a proto tyto polovodiče označujeme jako polovodiče typu P. Pokud polovodič typu N a P spojíme dohromady, začnou se elektrony samovolně pohybovat směrem $\mathrm{k}$ polovodiči typu $\mathrm{P}$ a díry se začnou pohybovat $\mathrm{k}$ polovodiči typu $\mathrm{N}$. V místech, kde jsou tyto polovodiče spojeny, je bariéra, která brání elektronům a dírám v pohybu přes celý polovodič. Při ozáření FTV článku slunečním světlem se tato bariéra překoná a elektrony proniknou do polovodiče typu P a díry do polovodiče typu N. Tím vznikne na FTV článku elektrické napětí. [4]

\subsubsection{Druhy FLV panelů}

\section{Křemíkový krystalický solární panel}

Pro výrobu křemíkových panelů se používá monokrystalický nebo polykrystalický křemík. Polykrystalický nitrid křemíku je polovodičový materiál, na který jsou připevněny mřǐžky elektrod. V dnešní době nových technologií dokážeme $\mathrm{z}$ obou vyprodukovat téměř stejné množství napětí. $Z$ toho vyplývá, že do využívání FTV panelů začíná promlouvat výhodnější 
cena výroby. Na začátcích výroby FTV panelů byly prokazatelně méně účinnější polykrystalické panely, avšak byly znatelně levnější. [5]

\section{Tenkovrstvé solární panely}

Tenkovrstvé solární panely jsou jako druhé na trhu, a zatím jako jediné. Jednotlivé články jsou tady nanesené př́imo na sklo, nebo na plastovou fólii. Účinnost tenkovrstvých článků je obvykle nižší než u krystalických panelů. Výhodou je, že výroba elektrického napětí vzniká při nízké intenzitě dopadajícího světla. Tenkovrstvé články mají mnohonásobně tenčí aktivní polovodičovou vrstvu a současně větší účinnost. Typickým představitelem je technologie CIGS neboli CIS. Poté lze vynechat ochranné tvrzené sklo, které tvoří u krystalických panelů 90\% hmotnosti. [5]

\section{Perovskitové solární panely}

Možná jedna z nejbližších budoucností fotovoltaických panelů jsou právě perovskitové solární panely. Jedná se především o složení halogenů, jakým je např́íklad chlor s olovem. Výhodou je možnost budoucí instalace např́klad do skleněných tabulí výplní otvorů, jako jsou prosklené dveře, okna, skleněné fasády podobně. [5]

\section{Organický solární panel}

Úplnou budoucností jsou solární panely organické. Tyto solární panely jsou prozatím vyvíjeny na univerzitě v Tel Avivu a jeho technologie využívá geneticky upravované bílkoviny a nanotechnologie. Tyto solární panely by neměly vůbec obsahovat žádné toxické prvky a měly by být zakomponovány na jakýkoliv materiál.

Elektrické napětí těchto panelů spočívá na bázi fotosyntézy. Jedním z nejlepších a nejdůležitějších aspektů je ekologie a výrobní cena solárního panelu. [5]

Fotovoltaické dvouplášt'ové panely (PV-DSF) jsou v poslední době častým řešením ke snížení spotřeby energie budov. Autoři článku [6] navrhují systém, kdy povrchová teplota fotovoltaického modulu a vnik tepla do tohoto systému je řízen nuceným větráním. Výsledky článku jasně ukazují, že správné kombinace vzduchové dutiny a rychlosti vzduchu výrazně sníží koeficient slunečního tepelného zisku a zlepší výkon fotovoltaického systému.

Stavebně integrované fotovoltaiky (BIPV) ve spojení s materiály pro změnu fáze (PCM) jsou předmětem dalšího článku [7]. Integrované fotovoltaiky nabízí prríležitosti ke snížení teploty fotovoltaického panelu za účelem zvýšení celkové účinnosti BIPV s využitím odebraného tepla pro řízení energetické zátěže budovy.

Fotovoltaické fasády s tepelnou regulací pasivním vzduchovým kanálem poskytují z hlediska nákladů efektivní opatření pro zlepšení přeměny solární energie na elektrickou energii. Autor Han ve své studii [8] představuje 2D numerické zkoumání charakteristik proudění tekutiny a přínosu tepla uvnitř pasivního chladícího vzduchového kanálu vytvořeného dvěma svislými rovnoběžnými stěnami. Jedna stěna je ohřivána absorbovaným teplem fotovoltaickými články ze slunečního záření. Výsledky ukazují ekonomický způsob uvolňování tepla ve prospěch výroby fotovoltaické energie otevřeným vzduchovým kanálem za fotovoltaickým panelem.

\subsubsection{Výroba a složení FLV panelu}

FTV panel vzniká spojením několika modulů pomocí pájecí pasty. Pájecí drát se zahřeje pomocí pájky a moduly se umístí do speciálního stojanu. Po dokončení pájení se moduly čistí pomocí ultrazvuku ve vodě o teplotě $60{ }^{\circ} \mathrm{C}$. Poté se moduly pájí ve skupinách. Moduly se umístí do rámu, do jehož obvodu se vsune kovový proužek, který všechny moduly pospojuje. Ten slouží i jako vodič. Poté se moduly přemístí na průhlednou desku z vrstveného skla, která slouží jako základna nesoucí moduly. Její pevnost je zvýšena laminátovou folií. Nakonec se aplikuje těsnící folie, která bude moduly chránit. Laminace a vytvrzení panelu se provádí $\mathrm{v}$ hermeticky uzavřené rozehřáté peci na $80{ }^{\circ} \mathrm{C}$, z níž se vysaje vzduch. Po vyjmutí z pece jsou všechny 
součásti spojeny dohromady. Panel se umístí do plastového rámu a slepí. Poté se rám sešroubuje a panel je kompletní. [4]

V přepočtu $1 \mathrm{~m}^{2}$ krystalického fotovoltaického panelu je přibližně $17 \mathrm{~kg}$. Z toho $90 \%$ hmotnosti panelu tvoří ochranné tvrzené sklo, aby nedošlo k poškození naprríklad krupobitím nebo jinými klimatickými jevy. Základní samotná výrobní jednotka se skládá obvykle z 60-72 článků z krystalického křemíků. Tyto články jsou v ochranné vrstvě, která slouží proti přehřívání. Dále se FTV panel skládá ze zadního krytu panelu, na kterém je připevněná přípojná krabička pro napojení elektrické instalace. V přední části panelu se nachází už jen zmiňované tvrzené bezpečnostní sklo. Celý FTV panel je orámován hliníkovým rámem. Lze jej zabudovat i do mědi nebo nerezu. [9]

\subsection{5 Životnost a návratnost FLV panelư}

Životnost FTV panelů je samozřejmě daná výrobcem. Životnost FTV panelu je definována jako doba, po kterou jeho výkon neklesne více než o $20 \%$. Znamená to, že po tuto dobu panel poskytuje záruku min. $80 \%$ nominálního výkonu. Tato životnost je v současnosti u kvalitních panelů 30 až 40 let. V ideálním případě může být až 60 let. Panely mohou být funkční i po uplynutí doby jejich životnosti. Průměrná účinnost FTV panelů je v současné době $17-18$ \%. Návratnost investice je závislá na mnoho faktorech, zejména na množství denní spotřeby elektřriny.

Návratnost fotovoltaické elektrárny je daná výkonem panelu, dobou slunečního svitu, správnou údržbou panelů a podobně. Nelze tedy přsesně říct, kdy se investice vrátí. Za př́edpokladu ideálních podmínek, správném nainstalování a neprojektování lze odhadovat návratnost cca 510 let. [10]

\subsubsection{Vliv na životní prostředí}

FTV ke svému chodu nepotřebuje žádné palivo, protože funguje pouze na sluneční energii. Při jeho chodu tedy nedochází ke znečišt’ování ovzduší a vody, jako při zpracovávání fosilních paliv, např. uhlí a plynu. Jejich průmyslová výroba však může mít negativní vliv na životní prostředí, a to př́padnými úniky škodlivých látek do okolního prostředí místa výroby. Pro představu $1 \mathrm{~m}^{2} \mathrm{FTV}$ panelu ušetř́ za 1 rok $1 \mathrm{t} \mathrm{CO}_{2}$ při výrobě energie $\mathrm{v}$ tepelných elektrárnách. FTV články se proto vyrábějí $\mathrm{v}$ uzavřených prostorách, takže lze tyto úniky co nejvíce eliminovat. Po uplynutí životnosti panelů se tyto panely recyklují, takže nebudou přispívat $\mathrm{k}$ hromadění tzv. elektroodpadu. Faktem tedy je, že FVT má spíše pozitivní dopad na životní prostředí, protože nahrazuje neobnovitelné zdroje energie. [11]

Účinky solární fotovoltaické energie na životní prostředí byly zkoumány v následujícím článku [12]. Solární fotovoltaická energie patří druhy obnovitelné energie s velkou pozorností díky svému nízkém znečištění. Solární fotovoltaická technologie má však pozitivní i negativní dopady na životní prostředí. Mezi negativní účinky výroby solárních fotovoltaických systému patř́i znečištění odpadních vod a odpadních plynů. Solární panely jsou také zdrojem světelného znečištění. Nesprávná likvidace solárních článků na konci jejich životnosti škodí životnímu prostředí díky zápachu a negativnímu vlivu na půdu.

\section{METODY A PŘíPADOVÁ STUDIE}

\subsection{Umístění solárních panelů na fasádu}

Solární panely lze umístit na fasádu z architektonického důvodu, nebo že na střešní konstrukci jej nelze umístit. Nutno zmínit, že nejlepší účinnost fotovoltaických panelů je v př́padě doi.org/10.51704/cjce.2020.vol6.iss2.pp59-70 
nainstalování sklonu vůči Slunci ve $30^{\circ}-40^{\circ}$. Dalším důležitým aspektem při umístění FTV panelů je orientace vůči světovým stranám. Ideálním umístěním je na jižní stranu. Naopak nevhodné je umístění na severní stranu.

$\mathrm{Na}$ fasádě mohou FTV panely být umístěny v $90^{\circ}$ a sloužit jako obklad větrané fasády. Toto umístění je nejčastější z důvodu architektonického vzhledu. Dále slouží zároveň jako obklad větrané fasády. Další možností je instalace pod úhlem. Avšak dojde ke zvětšení účinnosti výroby elektrické energie, působí nevzhledným dojmem. Zároveň ale může dojít k zastínění vnitřních prostorů. Taková instalace by byla vhodná např́klad pro kancelářské prostory a podobně.

V popsané případové studii bylo zvoleno umístění FTV ve variantě b) v $90^{\circ}$, pouze z jižní strany objektu.

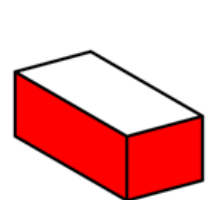

a)

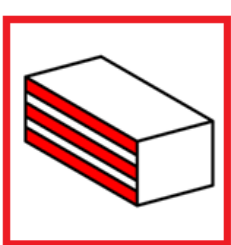

b)

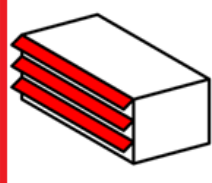

c)

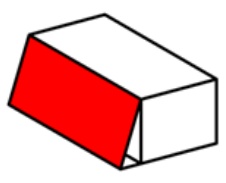

d)

Obr. 2 Umístění FLV na fasádě, varianta b) [13]

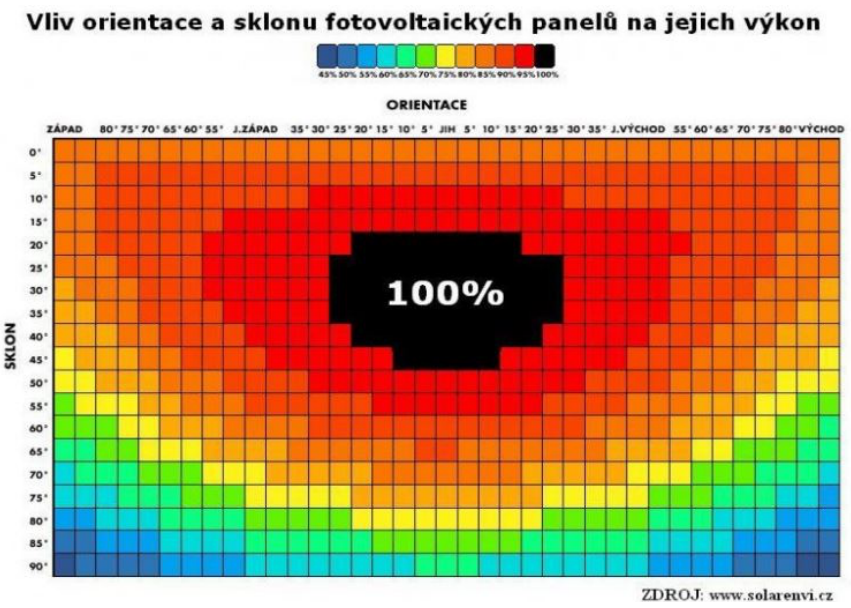

Obr. 3 Vliv orientace a sklonu FTV panelů na výkon [14]

\subsection{Návrh a výpočet spotřeby elektrické energie}

V rámci př́ípadové studie je uvažováno s možností využívat solární energii pro potřebu v bytovém domě. Bytový dům se skládá ze tř́i nadzemních podlaží a jednoho podzemního podlaží. V každém nadzemním podlaží jsou tři bytové jednotky. V tabulce č. 1 jsou uvedeny předběžné spotřebiče $\mathrm{v}$ domácnostech a jejich průměrný čas zapnutí. Solární panely jsou ukotveny na nosný rošt, který je ukotven pomocí speciálních konzolí k obvodové nosné zdi. Vyrobená elektrická energie bude ukládána do LiFePO4 akumulátorů. V př́padě přebytku elektrické energie bude předávána do distribuční sítě dodavatele elektrické energie. Veškeré tyto výpočty jsou vypočteny za daných klimatických podmínek na konkrétní stavbě bytového domu. 


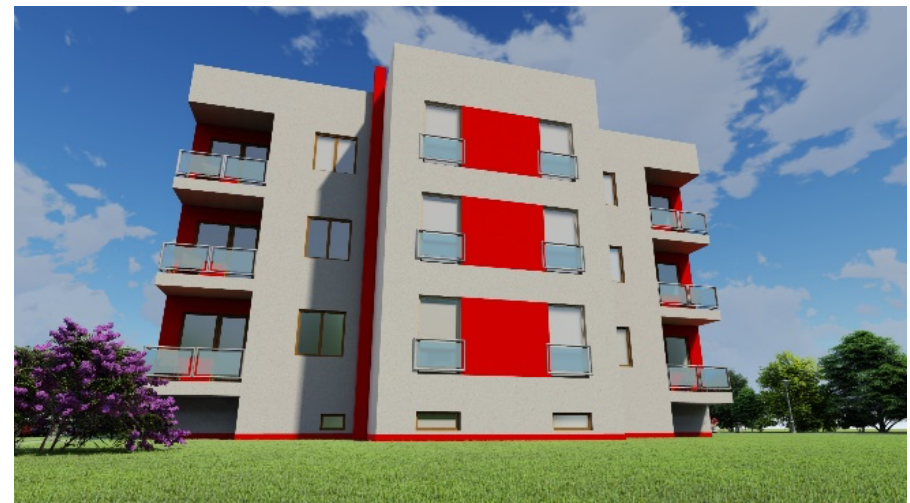

Obr. 4 Referenční objekt: Bytový dům

\section{Základní vstupní údaje}

Solární panel SUNPOWER MONO

Rozměr

Typ buněk

Nominální výkon

panelu

Váha $1 \mathrm{~m}^{2}$

Záruka výrobce

Max. účinnost panelu

Úhel montáže
Atypické

Monokrystalické

$400 \mathrm{Wp}$

cca $12 \mathrm{~kg}$

25 let

$19,4 \%$

$90^{\circ}$
Jmenovité napětí

$43,4 \mathrm{~V}$

Max. proud při zátěži

$9,22 \mathrm{~A}$

Napětí naprázdno

$52,7 \mathrm{~V}$

Max. systémové napětí

$1000 \mathrm{~V}$

Celková plocha FTV panelů $\quad 53,6 \mathrm{~m}^{2}$

Průměrná denní doba slunce 5 hodin

Účinnost panelu ve sklonu $\quad 70 \%$ $90^{\circ}$

V tabulce č. 1 je výpočet spotřeby elektrické energie za 1 rok. Ve výpočtu je přibližná doba spotřebičů, při jaké době je zapnutý. V bytovém domě se nachází celkem 9 bytových jednotek. Každá bytová jednotka spotřebuje denně přibližně $23,6 \mathrm{kWh}$. Za jeden den je spotřebováno 212,0 kWh elektrické energie. Celková spotřeba elektrické energie bytového domu za 1 rok činní 77388 kWh.

\begin{tabular}{|c|c|c|c|}
\hline Druh spotřebiče & $\begin{array}{c}\text { Průměrný př́kon } \\
(\mathbf{k W})\end{array}$ & $\begin{array}{c}\text { Čas spotřebiče } \\
(\mathbf{h})\end{array}$ & $\begin{array}{c}\text { Spotřeba za } \\
\text { den }(\mathbf{k W h})\end{array}$ \\
\hline Osvětlení v domácnosti & 0,80 & 2,5 & 2,0 \\
\hline Elektrický bojler 200 I & 2,20 & 1 & 2,2 \\
\hline El. vysoušeč vlasů & 2,30 & 0,15 & 0,3 \\
\hline Kombinovaná chladnička & 0,30 & 1 & 0,3 \\
\hline Rychlovarná konvice & 2,20 & 0,25 & 0,6 \\
\hline MikrovInná trouba & 0,90 & 0,25 & 0,2 \\
\hline Vestavná trouba & 3,30 & 0,5 & 1,7 \\
\hline El. indukční varná deska & 6,50 & 1 & 6,5 \\
\hline El. digestoř & 0,08 & 1 & 0,1 \\
\hline Myčka na nádobí & 0,80 & 1,5 & 1,2 \\
\hline Pračka na prádlo & 1,00 & 1 & 1,0 \\
\hline Sušička na prádlo & 4,50 & 1 & 4,5 \\
\hline Wifi router & 0,01 & 24 & 0,2 \\
\hline TV - LCD & 0,20 & 2 & 0,4 \\
\hline
\end{tabular}




\begin{tabular}{|c|c|c|c|}
\hline Vysavač & 2,00 & 0,15 & 0,3 \\
\hline \multicolumn{1}{|c|}{ Žehlička } & 1,80 & 0,3 & 0,5 \\
\hline PC, notebook, elektronika & 0,80 & 2 & 1,6 \\
\hline Celková spotřeba elektrické energie 1 bytové jednotky na den (kWh) & $\mathbf{2 3 , 6}$ \\
\hline \multicolumn{2}{|l|}{ Počet bytových jednotek v bytovém domě (ks) } & $\mathbf{9}$ \\
\hline Celková spotřeba elektrické energie bytového domu na den (kWh) & $\mathbf{2 1 2 , 0}$ \\
\hline $\begin{array}{l}\text { Celková spotřeba elektrické energie bytového domu za 1 rok } \\
\text { (kWh) }\end{array}$ \\
\hline
\end{tabular}

Tab. 1 Spotřeba elektrické energie bytového domu

\begin{tabular}{|l|c|}
\hline Výkon jednoho panelu na $1 \mathrm{~m}^{2}$ (Wp) za 1 hodinu & 400 \\
\hline Účinnost FTV panelu ve sklonu 90 $(\%)$ & 70 \\
\hline Skutečný výkon jednoho panelu na 1 $\mathrm{m}^{2}$ (Wr) za 1 hod. & 280 \\
\hline Celková plocha FTV panelů (m²) & 53,6 \\
\hline Vyrobená elektrická energie za 1 hodinu (kW) & 15,01 \\
\hline Průměrná doba denního svitu slunce (hodin) & 5 \\
\hline Celkem vyrobená el. energie za 1 den (kWh) & $\mathbf{7 5 , 0 4}$ \\
\hline Celkem vyrobená el. energie za 1 rok (kWh) & $\mathbf{2 7} \mathbf{3 8 9 , 6}$ \\
\hline
\end{tabular}

Tab. 2 Výroba elektrické energie FTV elektrárny za 1 rok

\begin{tabular}{|c|c|c|c|c|c|}
\hline $\begin{array}{l}\text { Doba } \\
\text { (rok) }\end{array}$ & $\begin{array}{c}\text { Účinnost } \\
\%\end{array}$ & $\begin{array}{l}\text { Vyrobeno } \\
\text { (kWh) }\end{array}$ & $\begin{array}{l}\text { Součet po } 5 \\
\text { letech (kWh) }\end{array}$ & $\begin{array}{l}\text { Součet po } 10 \\
\text { letech (kWh) }\end{array}$ & $\begin{array}{l}\text { Součet po } 15 \\
\text { letech (kWh) }\end{array}$ \\
\hline 1 rok & 70 & 27389,6 & \multirow{5}{*}{133035,2} & \multirow{10}{*}{256288,4} & \multirow{15}{*}{369759,6} \\
\hline 2 rok & 69 & 26998,3 & & & \\
\hline 3 rok & 68 & 26607,0 & & & \\
\hline 4 rok & 67 & 26215,8 & & & \\
\hline 5 rok & 66 & 25824,5 & & & \\
\hline 6 rok & 65 & 25433,2 & \multirow{5}{*}{123253,2} & & \\
\hline 7 rok & 64 & 25041,9 & & & \\
\hline 8 rok & 63 & 24650,6 & & & \\
\hline 9 rok & 62 & 24259,4 & & & \\
\hline 10 rok & 61 & 23868,1 & & & \\
\hline 11 rok & 60 & 23476,8 & \multirow{5}{*}{113471,2} & \multirow{5}{*}{113471,2} & \\
\hline 12 rok & 59 & 23085,5 & & & \\
\hline 13 rok & 58 & 22 694,2 & & & \\
\hline 14 rok & 57 & 22303,0 & & & \\
\hline 15 rok & 56 & 21911,7 & & & \\
\hline
\end{tabular}

Tab. 3 Výpočet výroby elektrické energie v následujících letech

Dalším postupem výpočtu bylo vypočítáno, kolik fotovoltaická elektrárna na fasádě bytového domu dokáže vyrobit elektrické energie. Důležitým aspektem při výpočtu je výkon FTV panelu. Navržený FTV panel o výkonu $400 \mathrm{Wp}$ je připevněn pod úhlem $90^{\circ}$. Tento úhel je nežádoucí vůči výkonu panelu. Jeho výkon klesne na 70 \%. Fotovoltaická elektrárna má celkem plochu doi.org/10.51704/cice.2020.vol6.iss2.pp59-70 
$53,6 \mathrm{~m}^{2}$. Nejdůležitější hodnotou při výpočtu je i průměrný denní sluneční svit. V tomto případě je uvažován sluneční svit 5 hodin/den. V posledních letech $(2017,2018$ a 2019) je průměrný denní sluneční svit 8 hodin. Uvažováno bylo pouze 5 hodin slunečního svitu, z důvodu menší výroby elektrické energie a dřívější eventuální finanční návratnosti FTV elektrárny.

Fotovoltaické elektrárny mají životnost 20-25 let. Při výpočtu výroby elektrické energie bylo uvažováno 15 let životnosti z důvodu, že finanční návratnost FTV elektráren je mezi 10-15 rokem na fasádách budov. Tabulka č. 3. znázorňuje pokles výroby energie s každým rokem o $1 \%$.

V tabulce č. 3 je patrné, že každým užívaným rokem klesne výroba elektrické energie FTV fasády na bytovém domě o 39,31 kWh. Během 5 roku až 10 roku klesne výroba elektrické energie o 9782,0 kWh. Porovnání s vyrobenou elektrickou energii z fotovoltaické fasády za 1 rok a spotřebě elektrické energie bytového domu za 1 rok je kolem 1/3.

\section{VÝSLEDKY}

\subsection{Porovnání pořizovací ceny FTV elektrárny a ceny ušetřené elektrické energie}

Cílem finančního porovnání FTV elektrárny je zjistit, za jakou dobu je FTV elektrárna výdělečná. To znamená, za jakou dobu se vrátí pořizovateli původní investované náklady.

V tabulce č. 4. je spočítán náklad na pořízení FTV elektrárny na fasádu bytového domu. Při výpočtu jsou uvažovány administrativní práce, samotná instalace a dodání FTV elektrárny na staveniště a její montáž. Celkový náklad na pořízení FTV elektrárny činní 1359 360,- Kč. V rámci pořízení FTV elektrárny není využito dotací Zelená úsporám.

\begin{tabular}{|l|c|c|c|}
\hline \multicolumn{1}{|c|}{ Druh materiálu } & Cena Kč & Počet ks & Celkem cena \\
\hline $\begin{array}{l}\text { Vypracování projektové } \\
\text { dokumentace }\end{array}$ & 3500 & - & 3500 \\
\hline $\begin{array}{l}\text { FTV panel SUNPOWER MONO 400 } \\
\text { Wp }\end{array}$ & 6500 & 45 & 292500 \\
\hline Kabeláž solární $6 \mathrm{~mm}^{2}(100 \mathrm{~m})$ & 2500 & 5 & 12500 \\
\hline Konektory pro zapojení panelů & 20 & 90 & 1800 \\
\hline Kotevní systém solárních panelů & 130 & 132 & 17160 \\
\hline Stř́́dač napětí kombinovaný & 8900 & 1 & 8900 \\
\hline Regulátor napětí & 1500 & 2 & 3000 \\
\hline Akumulátor Storion smile 5 & 315000 & 3 & 945000 \\
\hline Montáž FTV elektrárny & 75000 & - & 75000 \\
\hline Cena celkem FTV elektrárny na bytový dům & & $\mathbf{1 3 5 9 3 6 0 ~ K c ̌ ~}$ \\
\hline
\end{tabular}

Tab. 4 Náklady na poř́zení FTV elektrárny na fasádu bytového domu

Dále je nutno využít vypočítaných hodnot z tabulky č. 3. - Výpočet výroby elektrické energie v následujících letech. Pro porovnání finanční návratnost elektrárny, je nutno vyrobenou elektřinu vynásobit cenou za 1 kWh. Průměrná cena za 1 kWh se udává cca $5,-$ Kč.

Cena vyrobené elektrické energie z FTV elektrárny na fasádě za 1 rok udává hodnotu ušetřených financí, které by bez pořízení FTV elektrárny bylo nutno zaplatit dodavateli, který dodává elektrickou energii z distribuční sítě. 


\begin{tabular}{|c|c|c|c|c|c|}
\hline $\begin{array}{l}\text { Doba } \\
\text { (rok) }\end{array}$ & $\begin{array}{c}\text { Účinnost } \\
\%\end{array}$ & $\begin{array}{l}\text { Vyrobeno } \\
\text { (kWh) }\end{array}$ & $\begin{array}{c}\text { Cena } \\
\text { za } \\
1 \mathrm{kWh}\end{array}$ & $\begin{array}{l}\text { Cena vyrobené el. } \\
\text { energie za daný rok }\end{array}$ & Návratnost \\
\hline 1 rok & 70 & 27389,6 & \multirow{15}{*}{5,0 Kč } & 136948,0 Kč & 136948,0 Kč \\
\hline 2 rok & 69 & 26998,3 & & 134991,6 Kč & 271 939,6 Kč \\
\hline 3 rok & 68 & 26607,0 & & 133035,2 Kč & 404974,8 Kč \\
\hline 4 rok & 67 & 26215,8 & & $131078,8 \mathrm{Kč}$ & 536053,6 Kč \\
\hline 5 rok & 66 & 25824,5 & & 129122,4 Kč & 665176,0 Kč \\
\hline 6 rok & 65 & 25433,2 & & 127166,0 Kč & 792342,0 Kč \\
\hline 7 rok & 64 & 25041,9 & & 125 209,6 Kč & 917551,6 Kč \\
\hline 8 rok & 63 & 24650,6 & & 123253,2 Kč & 1040804,8 Kč \\
\hline 9 rok & 62 & 24259,4 & & 121296,8 Kč & 1162 101,6 Kč \\
\hline 10 rok & 61 & 23868,1 & & 119340,4 Kč & 1281442,0 Kč \\
\hline 11 rok & 60 & 23476,8 & & 117384,0 Kč & 1398826,0 Kč \\
\hline 12 rok & 59 & 23085,5 & & 115427,6 Kč & 1514253,6 Kč \\
\hline 13 rok & 58 & 22694,2 & & 113471,2 Kč & 1627724,8 Kč \\
\hline 14 rok & 57 & 22303,0 & & 111514,8 Kč & 1739 239,6 Kč \\
\hline 15 rok & 56 & 21911,7 & & 109 558,4 Kč & 1848798,0 Kč \\
\hline
\end{tabular}

Tab. 5 Výpočet doby návratnosti vůči ceně

První rok ušetříme za elektrickou energii 136 948,0 Kč. Následující rok 134 991,0 Kč. Tudíž za dva roky užívání FTV elektrárny bychom ušetřili 271 939,6 Kč. Tímto postupem dojdeme k závěru, že během 11 let se dostaneme na hodnotu 1398826 Kč. V porovnání s pořizovací cenou FTV elektrárny, která činní 1359360 Kč, jsme schopni získat její pořizovací nákladovou cenu během 11 let zpět samostatně vyrobenou elektrickou energií.

\subsection{Grafické porovnání výpočtů}

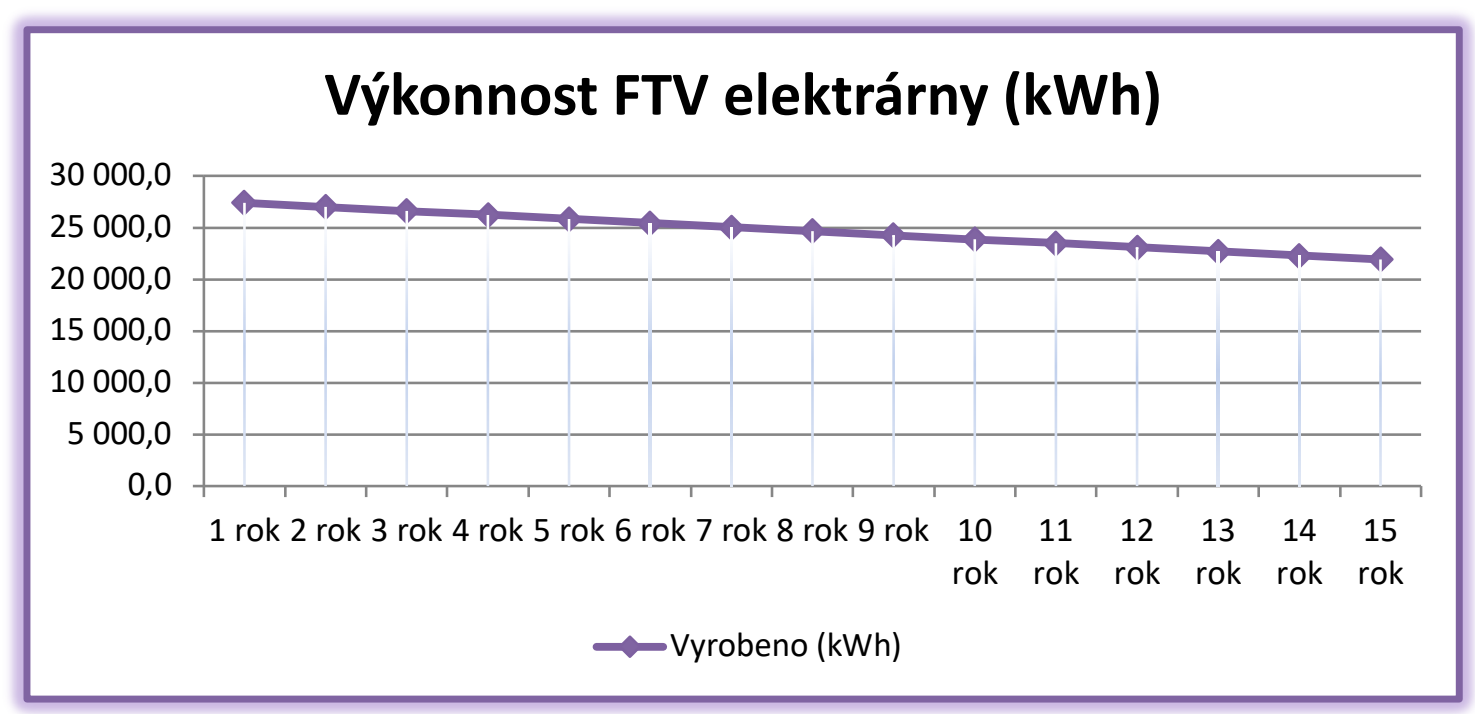

Obr. 5 Graf výkonnosti výroby FTV elektrárny za dobu 15 let 


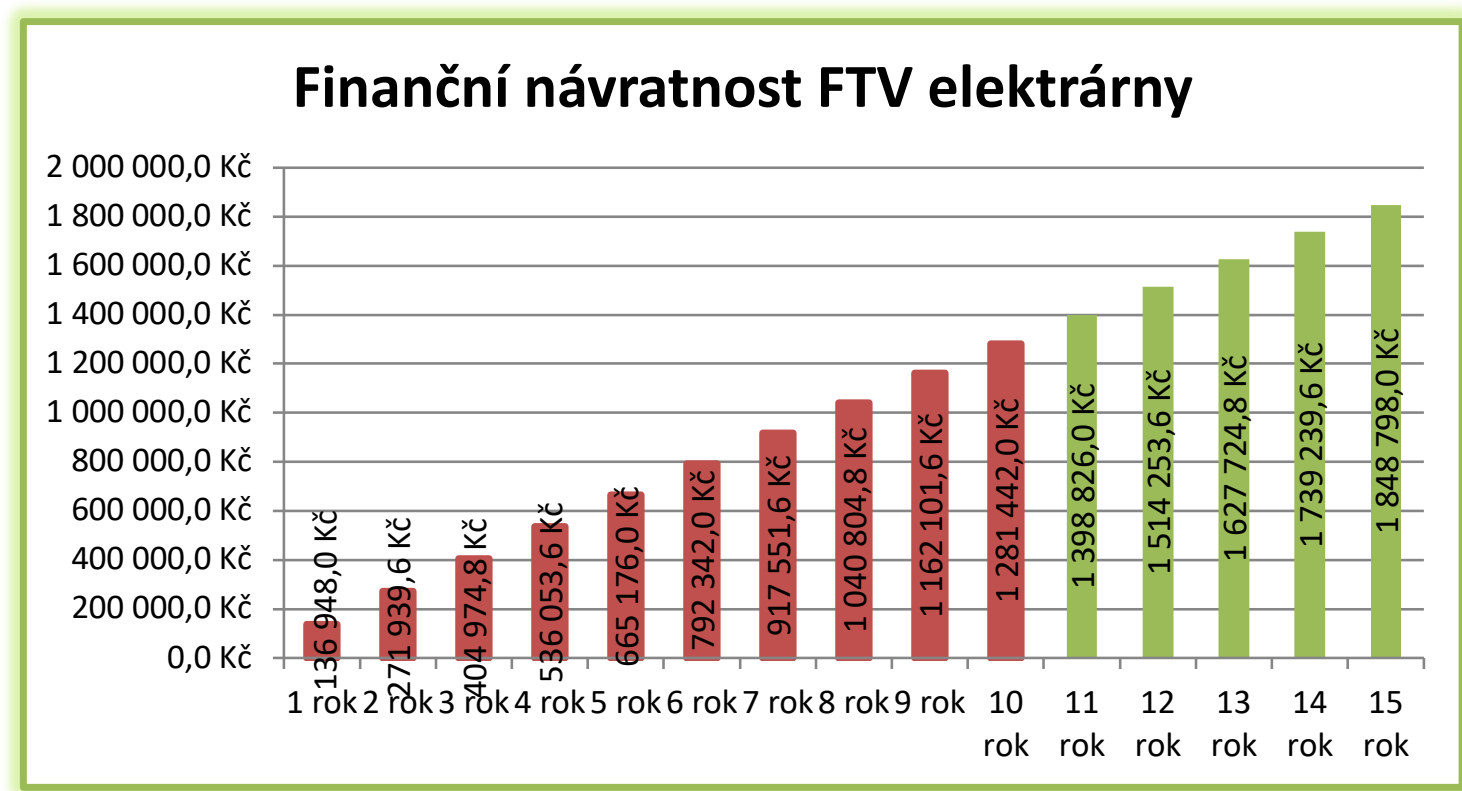

Obr. 6 Graf finanční návratnosti FTV elektrárny

\section{ZÁVĚR A DISKUZE}

Cílem tohoto článku bylo bližší seznámení s moderním využitím fotovoltaického systému, který se začíná v poslední době ve větší míře realizovat na různých objektech ve snaze využít sluneční záření jako obnovitelný zdroj energie.

V článku byl podrobněji rozveden návrh FTV elektrárny v bytovém domě. Dále byl proveden výpočet spotřeby elektrické energie bytového domu za 1 rok a výpočet vyrobené elektrické energie pomocí FTV elektrárny na fasádě bytového domu. Byla porovnána finanční nákladnost FTV elektrárny s návratností financí za vyrobenou elektrickou energií z FTV elektrárny na větrané fasádě bytového domu.

Závěrem bylo zjištěno, že během 11 let lze ušetřit 1398 826,0 Kč při pořizovací ceně FTV elektrárny na fasádě objektu 1359360 Kč. Z těchto výpočtů lze usoudit, že při životnosti 2025 let FTV panelů se zcela jednoznačně vyplatí pořízení této FTV elektrárny na bytovém domě. Dále lze FTV elektrárnu doporučit o ohledem na životní prostředí a ekologii.

\section{Poděkování}

Př́spěvek vznikl za podpory Standardního specifického výzkumu Vysokého učení technického v Brně s registračním číslem FAST-S-20-6338 a Juniorského specifického výzkumu s registračním číslem FAST-J-20-6359. 


\section{Použitá literatura}

[1] Redakce Proelektrotechniky.cz, Jak funguje fotovoltaický článek. In: Consulting Services [online]. 2013 [cit. 2021-01-10]. Dostupné z: http://www.proelektrotechniky.cz/vzdelavani/5.php

[2] ADIBPOUR, S., A. RAISI, B. GHASEMI, A.R. SAJADI a G. ROSENGARTEN. Experimental investigation of the performance of a sun tracking photovoltaic panel with Phase Change Material. Renewable Energy. 2021, 165, 321-333. ISSN 09601481. Dostupné z: doi:10.1016/j.renene.2020.11.022

[3] Fotovoltaická fasáda na RD [online]. [cit. 2021-01-10]. Dostupné z: http://www.designmag.cz/architektura/52242-nebusicka-vila-ma-fasadu-z-fotovoltaickychpanelu.html

[4] Konstrukce a výroba fotovoltaických článků a panelů [online]. [cit. 2021-01-10]. Dostupné z: http://www.odbornecasopisy.cz/elektro/casopis/tema/konstrukce-a-vyroba-fotovoltaickychclanku-a-panelu--10310

[5] Fotovoltaická fasáda [online]. [cit. 2021-01-10]. Dostupné z: https://www.eon-solar.cz/blog/2typy-solarnich-panelu-znate-kremikovy-tenkovrstvy-nebo-organicky

[6] PREET, Sajan, Manoj Kumar SHARMA, Jyotirmay MATHUR, Amartya CHOWDHURY a Sanjay MATHUR. Performance evaluation of photovoltaic double-skin facade with forced ventilation in the composite climate. Journal of Building Engineering. 2020, 32. ISSN 23527102. Dostupné z: doi:10.1016/j.jobe.2020.101733

[7] KANT, K., R. PITCHUMANI, A. SHUKLA a A. SHARMA. Analysis and design of air ventilated building integrated photovoltaic (BIPV) system incorporating phase change materials. Energy Conversion and Management. 2019, 196, 149-164. ISSN 01968904. Dostupné z: doi:10.1016/j.enconman.2019.05.073

[8] HAN, Jun, Lin LU, Hongxing YANG a Yuanda CHENG. Thermal regulation of PV façade integrated with thin-film solar cells through a naturally ventilated open air channel. Energy Procedia. 2019, 158, 1208-1214. ISSN 18766102. Dostupné z: doi:10.1016/j.egypro.2019.01.309

[9] Složeni FTV panelu [online]. [cit. 2021-01-10]. Dostupné z: https://www.fvesystemy.cz/Terminologie-a5 $0 . \mathrm{htm}$

[10] Recyklace fotovoltaických panelů na konci životnosti [online]. [cit. 2021-01-10]. Dostupné z: https://oze.tzb-info.cz/fotovoltaika/7868-recyklace-fotovoltaickych-panelu-na-konci-zivotnosti

[11] Ekologické hřichy a naděje fotovoltaické energie [online]. [cit. 2021-01-10]. Dostupné z: https://ekolist.cz/cz/zpravodajstvi/zpravy/ekologicke-hrichy-a-nadeje-fotovoltaicke-energie

[12] QI, Liqiang a Yajuan ZHANG. Effects of solar photovoltaic technology on the environment in China. Environmental Science and Pollution Research. 2017, 24(28), 22133-22142. ISSN 0944-1344. Dostupné z: doi:10.1007/s11356-017-9987-0

[13] Umistění FTV na fasádě [online]. [cit. 2021-01-10]. Dostupné z: https://www.solarniexperti.cz/jak-umistit-na-dum-solarni-panely/

[14] Vliv orientace FTV paneli̊ [online]. [cit. 2020-12-28]. Dostupné z: http://www.energie.snadno.eu/vase-strecha-a-caste--dotazy.html 